OPEN ACCESS

Approved by:

Frontiers in Neuroscience Editorial

Office,

Frontiers Media SA, Switzerland

${ }^{*}$ Correspondence: Kazuhiko Yanai yanai@med.tohoku.ac.jp

Specialty section: This article was submitted to

Neurodegeneration, a section of the journal

Frontiers in Neuroscience

Received: 06 September 2018 Accepted: 07 September 2018 Published: 25 September 2018

Citation:

Harada R, Okamura N, Furumoto $S$ and Yanai $K$ (2018) Corrigendum: Imaging Protein Misfolding in the Brain Using $\beta$-Sheet Ligands. Front. Neurosci. 12:675 doi: 10.3389/fnins.2018.00675

\section{Corrigendum: Imaging Protein Misfolding in the Brain Using $\beta$-Sheet Ligands}

\author{
Ryuichi Harada $^{1}$, Nobuyuki Okamura ${ }^{2}$, Shozo Furumoto ${ }^{3}$ and Kazuhiko Yanai ${ }^{1,3 *}$
}

${ }^{1}$ Department of Pharmacology, Tohoku University Graduate School of Medicine, Sendai, Japan, ${ }^{2}$ Division of Pharmacology, Tohoku Medical and Pharmaceutical University, Sendai, Japan, ${ }^{3}$ Cyclotron and Radioisotope Center, Tohoku University, Sendai, Japan

Keywords: proteinopathies, protein aggregates, $\beta$-sheet ligands, PET, tau

\section{A Corrigendum on}

Imaging Protein Misfolding in the Brain Using $\beta$-Sheet Ligands

by Harada, R., Okamura, N., Furumoto, S., and Yanai, K. (2018). Front. Neurosci. 12:585. doi: 10.3389/fnins.2018.00585

In the original article, there was a mistake in Figure 2 as published. The chemical structure of $\left[{ }^{11} \mathrm{C}\right] \mathrm{PBB} 3$ at top right was incorrectly described. The corrected Figure 2 appears below. The authors apologize for this error and state that this does not change the scientific conclusions of the article in any way.

The original article has been updated.

Conflict of Interest Statement: NO owns stock of CLINO Co. Ltd. NO and SF are scientific consultants for the CLINO Co. Ltd. RH and KY have no conflict of interest.

Copyright (C) 2018 Harada, Okamura, Furumoto and Yanai. This is an open-access article distributed under the terms of the Creative Commons Attribution License (CC BY). The use, distribution or reproduction in other forums is permitted, provided the original author(s) and the copyright owner(s) are credited and that the original publication in this journal is cited, in accordance with accepted academic practice. No use, distribution or reproduction is permitted which does not comply with these terms. 


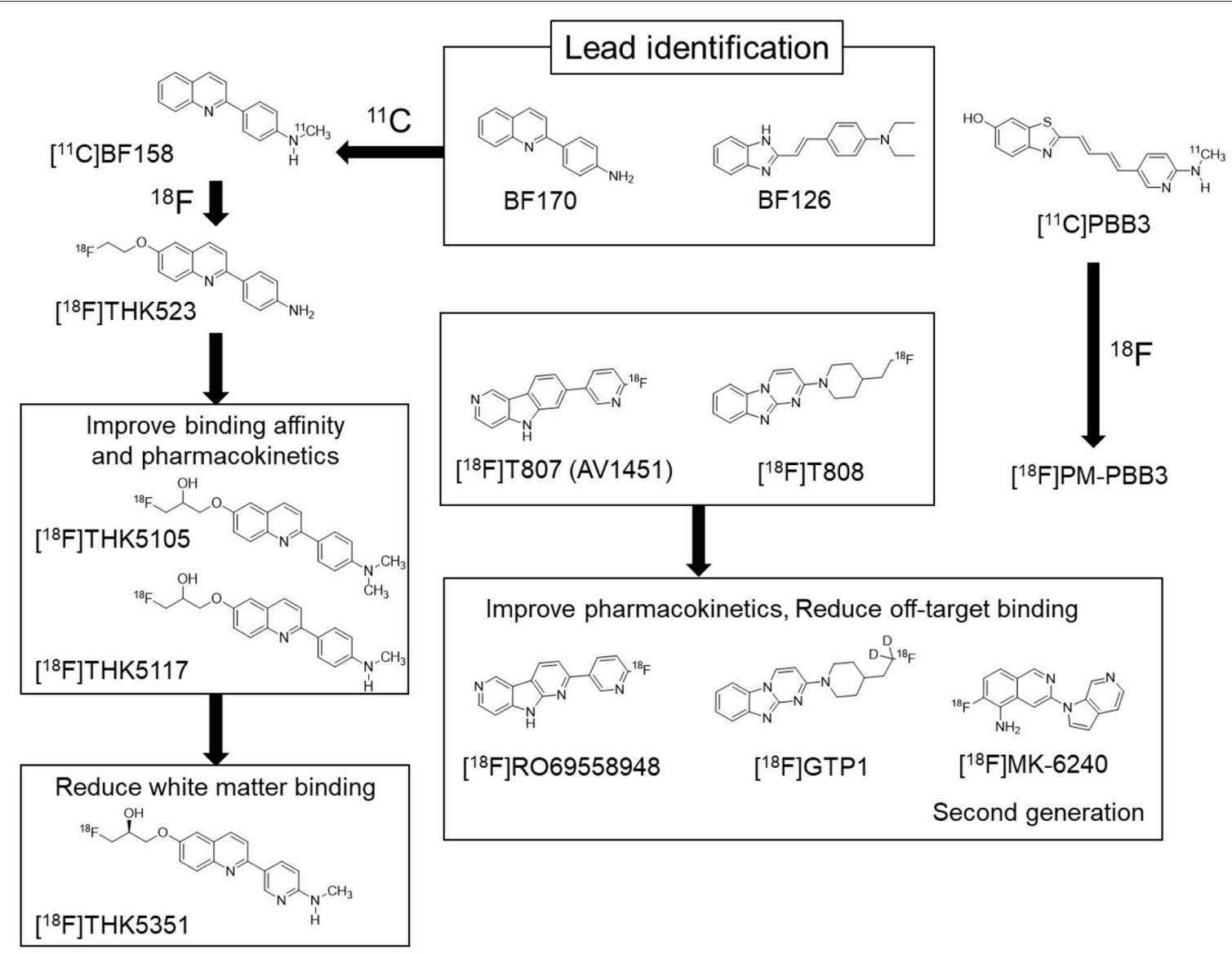

FIGURE 2 | Chemical structures and flowchart of the development of tau PET tracers. 